\title{
CHARACTERIZATION OF PASTA FROM HEAT MOISTURE TREATED WHEAT FLOUR AND GRAPE PEELS
}

\author{
*Mădălina IUGA ${ }^{\mathbf{1}}$, Silvia MIRONEASA ${ }^{\mathbf{1}}$ \\ ${ }^{I}$ Faculty of Food Engineering, Ştefan cel Mare University, Suceava, Romania \\ madalina.iuga@usm.ro \\ *Corresponding author: \\ Received $7^{\text {th }}$ May 2021, accepted $29^{\text {th }}$ June 2021
}

\begin{abstract}
Pasta nutritional and functional value can be enhanced by incorporating fiber-rich ingredients such as grape peels and/or by applying hydrothermal treatments to wheat flour. The purpose of this study was to characterize dough rheological behavior, chemical and sensory charateristics of pasta from heat moisture treated (HMT) wheat flour, native wheat-grape peels composite flour and treated wheat-grape peels flour mix. The results revealed that grape peels addition increased the nutritional value of pasta by raising the ash, fiber and polyphenols content, while HMT determined higher resistant starch values. The elastic and viscous moduli of dough increased when HMT was applied to wheat flour and/or grape peels were incorporated. The addition of grape peels led to higher glass transition temperature, while an opposite effect was observed for HMT. Both grape peels addition and HMT caused lower maximum creep and recovery compliances. Acceptable sensory scores were obtained for all the analysed samples, pasta from treated wheat grape peels composite flour was characterized as nutritious, fruity, sourish, pasta from treated wheat flour as elastic, gummy, sweet, pleasant, while pasta from native wheat-grape peels was characterized as satiating, fragile, innovative, sourish. These results evidenced the opportunity to increase the functional and nutritional value of pasta by applying physical modification of flour and/or by incorporating grape peels as a source of dietary fiber and bioactive compounds.
\end{abstract}

Keywords: wheat, grape peels, pasta, heat moisture treatment, rheology, sensory profile.

\section{Introduction}

Consumer preferences for food are constantly changing as society evolves and globalization occur. Vinification generates valuable byproducts that can be introduced in various forms into human nutrition. Their use has an advantage from both economic and environmental point of view. Recently, researchers have turned their attention to the development of new products by incorporating functional ingredients such as grape peels $[1,2]$.

Grape peels are considered sources of dietary fiber [3], being in the same time rich in phenolic compounds with antioxidant activity [4]. Consumption of foods with high amounts of fibers and antioxidants can reduce the occurrence of chronic diseases such as constipation, some cancers, cardiovascular diseases [5, 6]. Some studies revealed the influence of grape by-products on pasta quality. Gaita et al. [1] revealed that polyphenolics and anioxidant activities of wheat pasta enriched with grape peels were higher compared to the control, acceptable sensory characteristics being observed at levels up to $6 \%$. The results obtained by Sant'Anna et al. [7] showed a decrese of the sensory scores of fettuccini pasta when grape pomace was incorporated. In the study of Mironeasa et al. [8] on the effects of grape peels on wheat bread dough rheology it is 
stated that the viscoelastic moduli and the gelatinization temperature increased, depending on the addition level and particle size.

Starch-based foods are known to posess high glycemic index, which can lead to obesity and / or diabetes [9]. Reducing the glycemic index of foods can be achieved by introducing whole grains and pseudo-cereals, by using phenolic compounds that reduce the digestibility of starch [9] or by modifying flour by hydrothermal treatment in order to increase the content of slowly digestible starch and resistant starch, and to decrease digestible starch content $[10,11,12]$.

Hydrothermal treatments applied to wheat flour produce a reorganization of starch amylose and amylopectin chains, which leads to changes in crystallinity of the granules, viscosity, thermal and gelatinization properties and also digestibility. All these changes, along with protein denaturation that occur during hydrothermal treatment [13] and interactions between components, result in rheology and texture of final product modification [10, 11, 14]. Heat moisture treatment (HMT) supposes starch or flour treatment at high temperatures $(50<\mathrm{x}<120$ $\left.{ }^{\circ} \mathrm{C}\right)$ and low moisture $(10<\mathrm{x}<35 \%)$ for a given time [15].

HMT caused the decrease of wheat noodles slowly digestible starch and rapid digestible starch, while resistant starch contents were higher than of the native [16]. Chandla et al. [17] presented improved sensory characteristics of noodles made of HMT amaranth and corn starch compared to the native, mostly in terms of flavor, taste and overall acceptability. The study conducted by Lazaridou et al. [18] on wheat-barley rusk dough revealed that HMT caused an increase of elastic $\left(G^{\prime}\right)$ and viscous (G") moduli, while the compliances $(\mathrm{J})$ were lower compared to the control.

The aim of this study was to characterize dough and pasta products made of heat moisture treated wheat flour, wheat-grape peels composite flour and treated wheat- grape peels composite flour in terms of dough rheology, pasta chemical and sensory characteristics.

\section{Materials and methods}

Materials, treatment conditions and pasta production

Grape peels were obtained after manual separation from dry pomace of Feteasca Regala variety, then they were grinded and sieved to particle size $<180 \mu \mathrm{m}$.

Wheat flour of 650 type was treated according to the methodology presented in the literature [19]: moisture content was increased by adding corresponding amount of water in small portions with continuous stirring, then the samples were kept for $24 \mathrm{~h}$ in hermetically sealed containers for moisture equalization. Flour was treated in a closed system for the given time and temperature, and after cooling, it was grinded and sieved to particle size $<300 \mu \mathrm{m}$.

Dough was made by mixing flour with appropriate quantities of water to achieve $40 \%$ dough moisture in a Kitchen Aid mixer (Whirlpool Corporation, USA). After $15 \mathrm{~min}$ of resting, pasta modeling was done on a Kitchen Aid accessory for short pasta. Drying was made firstly at room temperature for $1 / 2 \mathrm{~h}$, then at $40{ }^{\circ} \mathrm{C}$ for $1 \mathrm{~h}$, at $80^{\circ} \mathrm{C}$ for 2 $\mathrm{h}$ and again at $40{ }^{\circ} \mathrm{C}$ for $2 \mathrm{~h}$ [20].

The samples considered in this study were obtained after previous optimizations. Control sample was made of untreated wheat flour, OTH sample was made of wheat flour treated at $85.30{ }^{\circ} \mathrm{C}$, for $1 \mathrm{~h}$ and $26.80 \%$ moisture [21], OPS was formed of native wheat flour with $4.62 \%$ grape peels [22] and OTPS sample was made from trated flour at $64.35{ }^{\circ} \mathrm{C}$, for $3 \mathrm{~h}$ and $26.65 \%$ moisture mixed with $4.94 \%$ grape peels [23].

\section{Dough rheology}

In order to characterize dough behavior during processing, dynamic oscillation and creep-recovery tests were applied using a Thermo-HAAKE MARS 40 rheometer 
(Karlsruhe, Germany) with parallel plates of $40 \mathrm{~mm}$ diameter, at a gap of $3 \mathrm{~mm}$. The dough was laminated to a thickness of $3 \mathrm{~mm}$ and allowed to rest for 1 hour before testing to relax internal strain. Then, the sample was placed in the measuring system and kept for $120 \mathrm{~s}$ at $20{ }^{\circ} \mathrm{C}$ before testing to allow relaxation and temperature stabilization. Excess dough was removed and a layer of vaseline was applied to the exposed edge to protect it from moisture loss during testing. Before evaluating the variation of the viscoelastic moduli with frequency, the limits of the linear viscoelastic region (LVR) were established by applying a strain range from 0.1 to $100 \mathrm{~Pa}$, at a constant oscillation frequency of $1 \mathrm{~Hz}$.

The variation of the elastic $\left(\mathrm{G}^{\prime}\right)$ and viscosous $\left(G^{\prime \prime}\right)$ modulus with frequency was evaluated by applying a constant strain of 15 $\mathrm{Pa}$ (in the LVR) and a frequency range from 0.1 to $20 \mathrm{~Hz}$.

In order to evaluate the behavior of pasta dough at heating, the dynamic oscillation tests were applied at a constant frequency of $1 \mathrm{~Hz}$, and the temperature was varied from 20 to $100{ }^{\circ} \mathrm{C}$ with a heating speed of $4^{\circ} \mathrm{C} /$ min. The elastic $\left(\mathrm{G}^{\prime}\right)$ and viscoscous mdoulus $\left(\mathrm{G}^{\prime \prime}\right)$ were recorded. The initial glass transition temperature $\left(\mathrm{T}_{\mathrm{i}}\right)$ determined at the minimum value of $\mathrm{G}^{\prime}$ and the glass transition temperature $\left(\mathrm{T}_{\mathrm{g}}\right)$ determined when the maximum value of $\mathrm{G}^{\prime \prime}$ was reached were identified [24].

Creep and recovery tests allowed the evaluation of compliance $(\mathrm{J})$ at a constant temperature of $20^{\circ} \mathrm{C}$ and a strain of $50 \mathrm{~Pa}$ as follows: the strain was applied for $60 \mathrm{~s}$, then it was removed to allow the sample to recover for $180 \mathrm{~s}$. Burgers mathematical model was applied [8, 25] for the experimental data obtained in the creep phase (equation 1) and in the recovery phase respectively (equation 2).

$$
\begin{aligned}
& J(t)=J_{C o}+J_{C m}\left(1-\exp \left(-1 / \lambda_{c}\right)\right)+t / \mu_{C o} \\
& J(t)=J_{\max }-J_{R o}-J_{R m}\left(1-\exp \left(-t / \lambda_{R}\right)\right)
\end{aligned}
$$

where: $\mathrm{J}_{\mathrm{Co}}\left(\mathrm{Pa}^{-1}\right)$ is the instantaneous compliance in the creep phase, $\mathrm{J}_{\mathrm{Ro}}\left(\mathrm{Pa}^{-1}\right)$ is the instantaneous compliance in the recovery phase, $J_{\mathrm{Cm}}\left(\mathrm{Pa}^{-1}\right)$ is the retarded elastic compliance in the creep phase, $\mathrm{J}_{\mathrm{Rm}}\left(\mathrm{Pa}^{-1}\right)$ is the retarded elastic compliance in the recovery phase, $\mathrm{t}$ (s) is the phase time, $\lambda_{\mathrm{C}}, \lambda_{\mathrm{R}}$ (s) are the retarded time in creep and recovery phase, $\mu_{\mathrm{Co}}(\mathrm{Pa} \cdot \mathrm{s})$ is the shear viscosity at time $0, J_{\max }\left(\mathrm{Pa}^{-1}\right)$ is the maximum compliance during creep phase, $\mathrm{J}_{\mathrm{r}}$ $\left(\mathrm{Pa}^{-1}\right)$ is the equilibrium compliance calculated as the sum of $J_{R o}$ and $J_{R m}$. Also, dough recovery capacity $\left(\mathrm{J}_{\mathrm{r}} / \mathrm{J}_{\max }\right)$ was determined.

\section{Pasta chemical composition}

Pasta moisture, ash, protein and lipids were measured according to SR EN ISO 712/2010, SR ISO 2171/2002, SR EN ISO 20483/2007, and SR 91/2007 respectively standards. Fiber content was measured by NIR spectrometry (FOSS 6500 NIR device, Silver Springs, SUA) and the carbohydrates were calculated by difference.

Megazyme kit was used to measure resistant starch (RS), slowly digestible starch (SDS) and rapid digestible starch (RDS) of boiled pasta. The principle of determination consisted of samples digestion with $\alpha$ amylase and amyloglucosidase for a specific time and spectrophotometric quantification of the glucose resulted.

The procedure described by Melili et al. [26] was used for extract preparation in order to quantify total polyphenols: grinded sample (2 g) was extracted with methanol $(80 \%)$ in a sonication bath at $37{ }^{\circ} \mathrm{C}$ and $45 \mathrm{~Hz}$ for 40 min. After filtration, the extract $(0.20 \mathrm{~mL})$ was mixed with $0.80 \mathrm{~mL}$ distilated water, Folin-Ciocalteu reagent $(0.50 \mathrm{~mL})$ and sodium carbonate $20 \%(2.50 \mathrm{~mL})$. The absorbance was read after $40 \mathrm{~min}$ of resting in the darkness at $725 \mathrm{~nm}$ on an UV-VISNIR Shimadzu 3600 (Tokyo, Japan) spectrophotometer. The content of total polyphenols was calculated from a calibration curve with gallic acid $\left(R^{2}=0.99\right)$.

Mădălina IUGA, Silvia MIRONEASA, Characterization of pasta from heat moisture treated wheat flour and grape peels, Food and Environment Safety, Volume XX, Issue 2-2021, pag. $91-100$ 


\section{Sensory profile of pasta}

Pasta sensory profile was established according to the descriptive method Check All the Attributes (CATA) described by Bustos et al. [27], with some modifications. A panel of 9 semitrained judges evaluated fresh boiled pasta in one session. The coded samples were randomly presented, water being provided for mouth cleaning. The terms used for characterization were previously discussed and established in the training session. Texture was characterized by the following attributes: grainy, pasty, sticky, al dente, seed, soft, gummy, elastic or fragile; color was evaluated as unpleasant or pleasant; flavor was characterized by sweet, back flavor, sourish, flavored, fruity or bitter; general aspect attributes used were healthy, tempting, tasty, light, natural, satiating, pleasant, artificial or nutritious. Global acceptability was evaluated on a scale from 1 to 9 points.

\section{Statistical Analysis}

All the measurements were performed in triplicate. Tukey post-hoc test was applied in order to underline significant differences $(p<$
0.05) between samples. The data of CATA analysis were processed using Principal Corespondence Analysis (PCoA). In order to identify the relationships between characteristics, Principal Component Analysis was applied. All the statistical analysis were made using XLSTAT for Excel 2021 version (Addinsoft, New York, SUA) software.

\section{Results and discussion}

\section{Chemical composition}

Pasta proximate composition is presented in Table 1. Significant higher $(p<0.05)$ ash content was observed for OPS and OTPS, samples containing grape peels. The obtained results underlined the positive effects of HMT and grape peels addition on fiber content which was enhanced compared to the control. The carbohydrates were lower in pasta from treated wheat flour (OTH) and pasta with grape peels (OPS) which could led to lower glycemic index. These results are due to the nutrients intake of grape peels, similar findings being reported by Acun and Gül [28] for baked products supplemented with grape pomace, seeds, seedless pomace.

Table 1.

Chemical and sensory characteristics of pasta

\begin{tabular}{|c|c|c|c|c|}
\hline Characteristic & Control & ОТН & OPS & OTPS \\
\hline Moisture* (\%) & $11.54 \pm 0.03^{\mathrm{a}}$ & $7.02 \pm 0.12^{\mathrm{d}}$ & $11.27 \pm 0.07^{\mathrm{b}}$ & $8.40 \pm 0.03^{c}$ \\
\hline $\operatorname{Ash} *(\%)$ & $0.56 \pm 0.02^{\mathrm{b}}$ & $0.58 \pm 0.07^{\mathrm{b}}$ & $0.71 \pm 0.08^{\mathrm{ab}}$ & $0.75 \pm 0.06^{\mathrm{a}}$ \\
\hline Lipids* (\%) & $0.11 \pm 0.01^{\mathrm{c}}$ & $0.31 \pm 0.05^{\mathrm{a}}$ & $0.19 \pm 0.02^{\mathrm{b}}$ & $0.27 \pm 0.01^{\mathrm{a}}$ \\
\hline Proteins* $(\%)$ & $12.33 \pm 0.09^{b}$ & $12.59 \pm 0.09^{\mathrm{ab}}$ & $12.68 \pm 0.09^{\mathrm{a}}$ & $12.42 \pm 0.16^{\mathrm{ab}}$ \\
\hline Fiber* $(\%)$ & $0.02 \pm 0.00^{c}$ & $1.55 \pm 0.05^{\mathrm{b}}$ & $1.45 \pm 0.05^{\mathrm{b}}$ & $2.35 \pm 0.05^{\mathrm{a}}$ \\
\hline Carbohydrates* $(\%)$ & $75.44 \pm 0.10^{\mathrm{b}}$ & $77.95 \pm 0.19^{\mathrm{a}}$ & $73.71 \pm 0.21^{\mathrm{c}}$ & $75.81 \pm 0.15^{\mathrm{b}}$ \\
\hline $\mathrm{RS}^{*}(\%)$ & $0.88 \pm 0.00^{\mathrm{d}}$ & $1.56 \pm 0.03^{c}$ & $1.61 \pm 0.00^{\mathrm{b}}$ & $2.24 \pm 0.01^{\mathrm{a}}$ \\
\hline SDS* $(\%)$ & $5.87 \pm 0.14^{\mathrm{b}}$ & $3.38 \pm 0.00^{\mathrm{a}}$ & $6.59 \pm 0.32^{\mathrm{d}}$ & $4.67 \pm 0.17^{\mathrm{c}}$ \\
\hline $\operatorname{RDS}^{*}(\%)$ & $23.80 \pm 0.04^{b}$ & $26.80 \pm 0.00^{\mathrm{d}}$ & $18.29 \pm 0.08^{\mathrm{a}}$ & $23.18 \pm 0.11^{\mathrm{c}}$ \\
\hline TP* ( $\mu \mathrm{g}$ GAE / g) & $93.00 \pm 0.83^{b}$ & $96.41 \pm 3.01^{b}$ & $129.89 \pm 2.38^{\mathrm{a}}$ & $124.43 \pm 1.89^{\mathrm{a}}$ \\
\hline Global acceptability & $8.41 \pm 0.04^{\mathrm{a}}$ & $8.00 \pm 0.00^{\mathrm{b}}$ & $7.78 \pm 0.03^{\mathrm{c}}$ & $7.55 \pm 0.05^{\mathrm{d}}$ \\
\hline
\end{tabular}

Resistant starch (RS) has been proved to be higher in products from heat moisture treated starch or flour [29], which is in agreement with our results. The increase of RS could be due to starch structure reorganization during HMT and/or to the starch-polyphenols and polyphenols inhibition effects on digestive enzymes $[12,30]$. Slowly (SDS) and rapid

Mădălina IUGA, Silvia MIRONEASA, Characterization of pasta from heat moisture treated wheat flour and grape peels, Food and Environment Safety, Volume XX, Issue 2 - 2021, pag. 91 - 100 
digestible (RDS) starch decreased when HMT was applied compared to the control, similar trend being reported by Li et al. [16] for noodles from HMT wheat flour. As it was expected, no significant changes $(p>0.05)$ of total polyphenols (TP) were observed between control and sample from treated flour $(\mathrm{OTH})$, while the addition of grape peels resuted in significant $(p<0.05)$ higher TP contents (Table 1). Gaita et al. [1] also reported increases of TP and antioxidant activity of pasta as the grape peels level was higher. It was stated that the polyphenols from grape pomace presented high bioaccesibility and availability for the intestinal absorption [31], the metabolism of phenolic compounds being directly influenced by hydrogen, ionic, covalent, and hydrophobic linkages with proteins [1].

\section{Dough rheology}

Frecuency sweep test revealed that the elastic and solid-like character of all pasta dough samples since $G^{\prime}>G^{\prime \prime}$ (Figure 1).

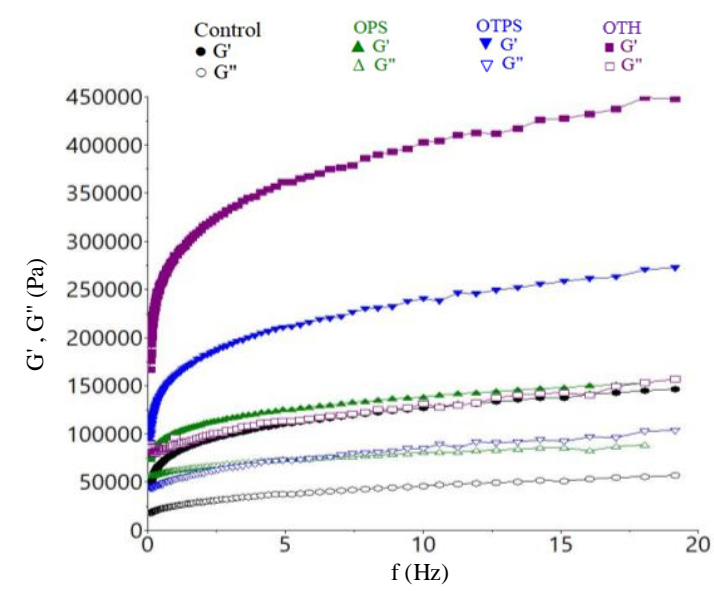

Fig.1. Variation of the elastic $\left(G^{\prime}\right)$ and viscous $\left(G^{\prime \prime}\right)$ moduli with frequency: OTH - sample from heat moisture treated wheat flour, OPS - sample from wheat-grape peels composite flour, OTPS - sample from treated wheat flour and grape peels

The addition of grape peels and wheat flour HMT determined higher elastic and viscous moduli compared to the control, probably due to the starch and proteins modifications during treatment and to the fiber content of grape peels which may compete with gluten for water $[8,29]$. The highest impact on $\mathrm{G}^{\prime}$ and $G^{\prime \prime}$ was observed for pasta made from HMT flour which may be related to the formation of protein and starch aggregates, leading to solubility and interactions between components changes [12].

The variation of $\mathrm{G}^{\prime}$ and $\mathrm{G}^{\prime \prime}$ with temperature is showed in Figure 2.

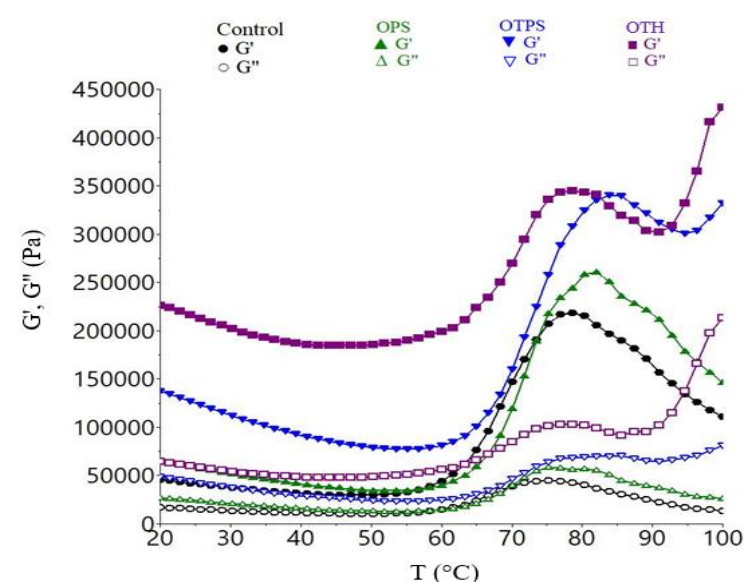

Fig. 2. Variation of the elastic $\left(\mathrm{G}^{\prime}\right)$ and viscous $\left(\mathrm{G}^{\prime \prime}\right)$ moduli with temperature: OTH - sample from heat moisture treated wheat flour, OPS - sample from wheat-grape peels composite flour, OTPS - sample from treated wheat flour and grape peels

Grape peels and HMT determined higher $\mathrm{G}^{\prime}$ and $\mathrm{G}^{\prime \prime}$ values compared to the control. In the first heating step, a decrease of $G^{\prime}$ up to a certain temperature value could be due to the protein denaturation phenomenon which led to water absorption capacity changes [8]. In the next step, a rapid increase of G' until the maximum gelatinization temperature was reached, followed by a decrease was observed which can be related to the gelatinization process that occurs at about 50 ${ }^{\circ} \mathrm{C}$. Dough samples made from HMT wheat showed different behavior in the second heating step, showing an increase of $\mathrm{G}^{\prime}$ and $\mathrm{G}^{\prime \prime}$ at the end of the test, at temperature $>90$ ${ }^{\circ} \mathrm{C}$. This trend could be explained by the gliadin content of the samples [32]. Heat moisture treatment showed a lowering effect on flour onset gelatinization temperature $\left(\mathrm{T}_{\mathrm{i}}\right)$ and glass transition (Figure 3). On the other hand, grape peels addition resulted in higher $\mathrm{T}_{\mathrm{i}}$ values compared to the control. These

Mădălina IUGA, Silvia MIRONEASA, Characterization of pasta from heat moisture treated wheat flour and grape peels, Food and Environment Safety, Volume XX, Issue 2-2021, pag. 91 - 100 
changes may be due to the interactions between starch components and lipids and/or to the bonds formed during HMT, similar findings being reported by Collar and Armero [33].

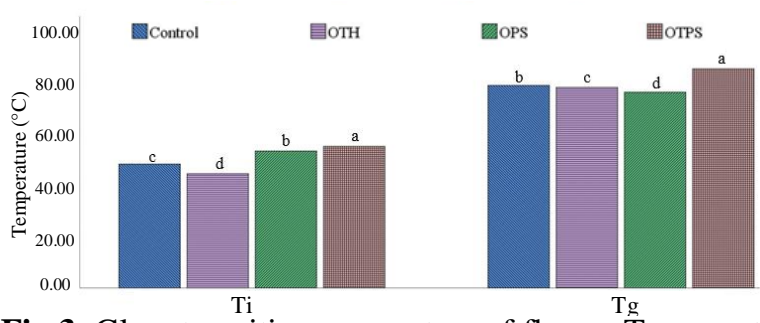

Fig.3. Glass transition parameters of flours: $T_{i}-$ onset temperature, $\mathrm{T}_{\mathrm{g}}$ - glass transition (peak) temperature, OTH - sample from heat moisture treated wheat flour, OPS - sample from wheat-grape peels composite flour, OTPS - sample from treated wheat flour and grape peels, a-d means followed by different letters in the same row are significantly different $(p<0.05)$

Creep and recovery tests could provide information about dough rigidity [8]. Dough compliances evolution in time is presented in Figure 4. HMT and grape peels addition determined higher resistance to deformation showed by the decrease of creep compliances compared to the control. Similar trend was reported by Mironeasa et al. [8] for bread dough enriched with 7 and $9 \%$ grape peels.

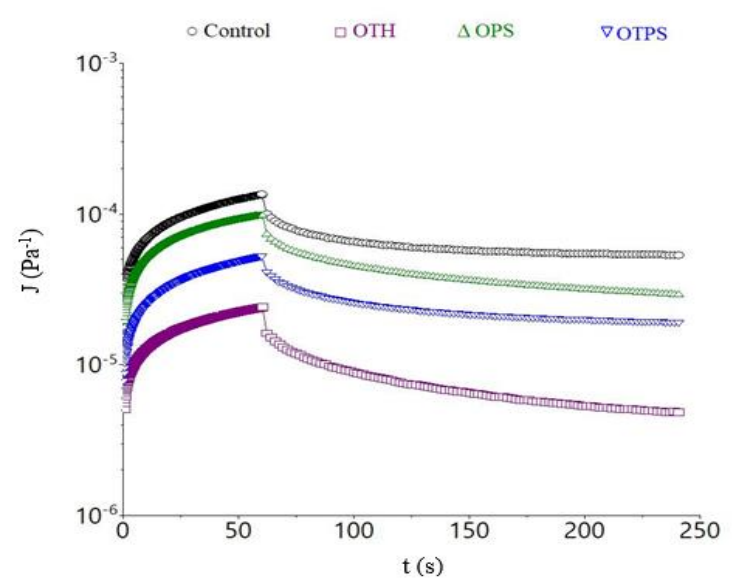

Fig. 4. Creep and recovery of pasta dough: OTH sample from heat moisture treated wheat flour, OPS sample from wheat-grape peels composite flour, OTPS - sample from treated wheat flour and grape peels

Lower values for Burger's parameters were obtained for samples from treated wheat flour and/or with grape peels (Table 2). Compared to the control, the instantaneous $\left(\mathrm{J}_{\mathrm{Co}}, \mathrm{J}_{\mathrm{Ro}}\right)$ and the retarded compliances $\left(\mathrm{J}_{\mathrm{Cm}}\right.$, $J_{R m}$ ) for both creep and recovery phases were lower for OTH, OPS and OTPS, indicating lower instant and retarded deformation which may be led to dough water content of the treated and/or enriched samples [34].

Table 2.

Burger's model parameters

\begin{tabular}{|c|c|c|c|c|}
\hline Parameter & Control & OTH & OPS & OTPS \\
\hline \multicolumn{5}{|l|}{ Creep phase } \\
\hline $\mathrm{J}_{\mathrm{Co}} \cdot 10^{5}\left(\mathrm{~Pa}^{-1}\right)$ & $3.89 \pm 0.31^{\mathrm{a}}$ & $0.72 \pm 0.01^{\mathrm{c}}$ & $2.82 \pm 0.23^{\mathrm{b}}$ & $1.17 \pm 0.04^{\mathrm{c}}$ \\
\hline $\mathrm{J}_{\mathrm{Cm}} \cdot 10^{5}\left(\mathrm{~Pa}^{-1}\right)$ & $10.01 \pm 0.01^{\mathrm{a}}$ & $3.51 \pm 0.20^{\mathrm{b}}$ & $9.06 \pm 0.86^{\mathrm{a}}$ & $4.51 \pm 0.35^{\mathrm{b}}$ \\
\hline$\lambda_{\mathrm{C}}(\mathrm{s})$ & $33.20 \pm 1.64^{\mathrm{bc}}$ & $43.94 \pm 1.21^{\mathrm{a}}$ & $30.82 \pm 1.97^{c}$ & $36.28 \pm 0.73^{b}$ \\
\hline$\mu_{\mathrm{Co}} \cdot 10^{-6}(\mathrm{~Pa} \cdot \mathrm{s})$ & $1.08 \pm 0.06^{\mathrm{c}}$ & $3.64 \pm 0.21^{\mathrm{a}}$ & $1.51 \pm 0.16^{\mathrm{c}}$ & $2.86 \pm 0.38^{b}$ \\
\hline $\begin{array}{l}\mathrm{J}_{\max } \cdot 10^{5}\left(\mathrm{~Pa}^{-1}\right) \\
\text { Recovery phase }\end{array}$ & $14.24 \pm 0.79^{a}$ & $3.39 \pm 0.10^{\mathrm{c}}$ & $10.81 \pm 0.81^{\mathrm{b}}$ & $4.91 \pm 0.36^{c}$ \\
\hline $\mathrm{J}_{\mathrm{Ro}} \cdot 10^{5}\left(\mathrm{~Pa}^{-1}\right)$ & $4.03 \pm 1.33^{\mathrm{a}}$ & $1.84 \pm 0.00^{\mathrm{b}}$ & $2.92 \pm 0.20^{\mathrm{ab}}$ & $1.67 \pm 0.28^{\mathrm{b}}$ \\
\hline $\mathrm{J}_{\mathrm{Rm}} \cdot 10^{5}\left(\mathrm{~Pa}^{-1}\right)$ & $5.59 \pm 1.15^{\mathrm{a}}$ & $0.67 \pm 0.00^{b}$ & $4.50 \pm 0.54^{\mathrm{a}}$ & $1.93 \pm 0.06^{\mathrm{b}}$ \\
\hline$\lambda_{\mathrm{R}}(\mathrm{s})$ & $42.53 \pm 11.90^{\mathrm{a}}$ & $9.89 \pm 0.00^{\mathrm{b}}$ & $45.78 \pm 2.00^{\mathrm{a}}$ & $37.40 \pm 2.24^{\mathrm{a}}$ \\
\hline $\mathrm{J}_{\mathrm{r}} \cdot 10^{5}\left(\mathrm{~Pa}^{-1}\right)$ & $9.61 \pm 0.31^{\mathrm{a}}$ & $2.51 \pm 0.00^{\mathrm{d}}$ & $7.42 \pm 0.50^{\mathrm{b}}$ & $3.60 \pm 0.35^{\mathrm{c}}$ \\
\hline $\mathrm{J}_{\mathrm{r}} / \mathrm{J}_{\max }(\%)$ & $67.51 \pm 4.27^{\mathrm{a}}$ & $74.19 \pm 2.32^{\mathrm{a}}$ & $68.68 \pm 1.02^{\mathrm{a}}$ & $73.33 \pm 1.71^{\mathrm{a}}$ \\
\hline \multicolumn{5}{|c|}{$\begin{array}{l}\text { OTH - sample from heat moisture treated wheat flour, OPS - sample from wheat-grape peels composite flour, OTPS - } \\
\text { sample from treated wheat flour and grape peels, } J_{C o}-\text { instantaneous compliance for creep phase, } J_{R o}-\text { instantaneous } \\
\text { compliance for recovery phase, } J_{C m}-\text { retarded elastic compliance for creep phase, } J_{R m}-\text { retarded elastic compliance for } \\
\text { recovery phase, } t-\text { phase time, } \lambda_{C}, \lambda_{R}-\text { retardation time, } \mu_{C o}-\text { zero shear viscosity, } J_{\max }-\text { maximum creep compliance } \\
\text { obtained at the end of the creep phase, } J_{\mathrm{r}}-\text { recovery compliance calculated as sum of } J_{R o} \text { and } J_{R m}, J_{\mathrm{r}} / J_{\max }-\text { dough recovery } \\
\text { capacity, a-d means followed by different letters in the same row are significantly different }(p<0.05)\end{array}$} \\
\hline
\end{tabular}

Mădălina IUGA, Silvia MIRONEASA, Characterization of pasta from heat moisture treated wheat flour and grape peels, Food and Environment Safety, Volume XX, Issue 2-2021, pag. $91-100$ 
Dough recovery capacity given by the ratio between $\mathrm{J}_{\mathrm{r}}$ and $\mathrm{J}_{\max }$ was higher for pasta dough made from treated wheat flour and/or with grape peels addition compared to the control. The results are in agreement with those reported by Mironeasa et al. [8] for dough with different levels and particle sizes of grape peels. The recovery capacity may provide information on dough macrostructure. For example, increased recovery capacity could be due to the presence of small molecules in dough system, while small values could be associated with large molecules [35].

\section{Sensory profile of pasta}

Both HMT and grape peels addition in wheat pasta resulted in lower global acceptability (Table 1). Sant'Anna et al. [7] also reported lower sensory characteristics score when grape pomace was incorporated in fettuccini pasta. Another study showed that the appearence of noodles made of HMT amaranth starch presented lower values compared to the samples from native starch [17]. Pasta attributes resulted from CATA analysis are presented in Figure 5. The first dimension (F1) explained $56.71 \%$ and the second one (F2) $29.65 \%$ of total inertia.

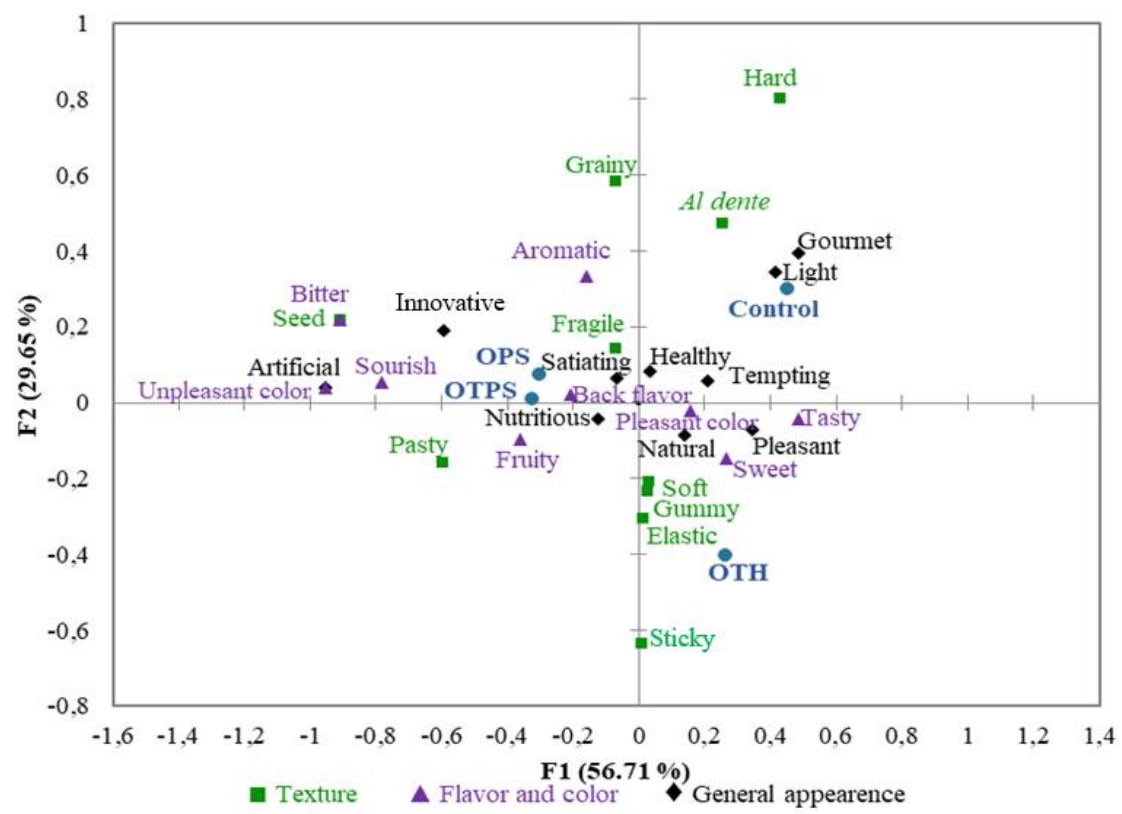

Fig. 5. Principal Corespondence Analysis (PCoA) results for pasta sensory attributes: OTH - sample from heat moisture treated wheat flour, OPS - sample from wheat-grape peels composite flour, OTPS - sample from treated wheat flour and grape peels

Control sample was characterized as light, gourmet, tempting, while OTH made of treated wheat flour was identified as being elastic, gummy, sweet, soft. Both samples containing grape peels were described as being nutritious, fruity, sourish, fragile, innovative, with pleasant color and satiating, being positionated closely one to each other. Grape peels were responsible for the back flavor identified by the panelists probably due to the polyphenol's presence.

\section{Relationships between characteristics}

Principal Component Analysis bi-plot exhibiting relationships between characteristics and samples is shown in Figure 6. The first principal component (PC1) explained $47.10 \%$ of the total variance, while the second one (PC2) explained $40.92 \%$.

Mădălina IUGA, Silvia MIRONEASA, Characterization of pasta from heat moisture treated wheat flour and grape peels, Food and Environment Safety, Volume XX, Issue 2-2021, pag. $91-100$ 


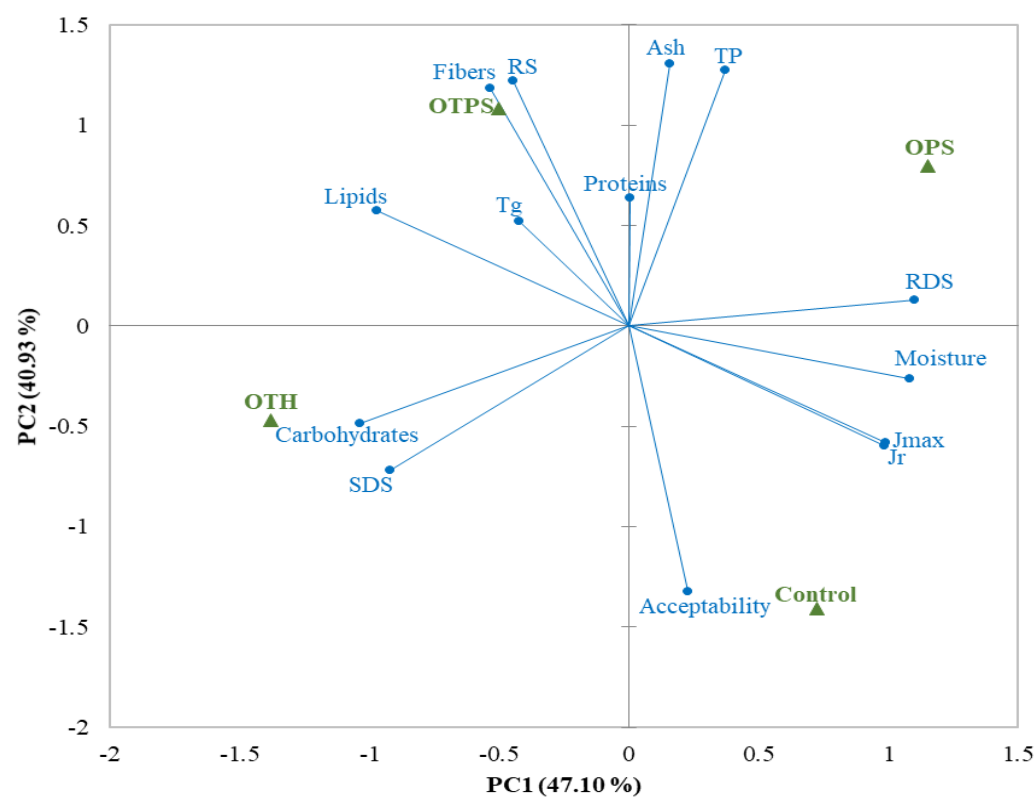

Fig. 6. Principal Component Analysis bi-plot: OTH - sample from heat moisture treated wheat flour, OPS sample from wheat-grape peels composite flour, OTPS - sample from treated wheat flour and grape peels, RS resistant starch, SDS - slowly digestible starch, RDS - rapid digestible starch, $T_{\mathrm{g}}$ - glass transition temperature,

$\mathrm{TP}$ - total polyphenols, $\mathrm{J}_{\mathrm{r}}$ - recovery compliance, $\mathrm{J}_{\max }$ - maximum creep compliance

PC1 was associated with RDS, moisture, $\mathrm{J}_{\max }$, carbohydrates, lipids, while PC2 was associated with RS, ash, TP fibers contents and global acceptability. RDS was strongly correlated with moisture content $(r=0.96, p$ $<0.05)$, while RS content was positively correlated to fibers $(r=0.98, p<0.05)$, which was in agreement with the statement that RS behavior in the digestion system is similar to that of fibers [36]. Moisture was significantly $(p<0.05)$ related to the creep and recovery complinances $(r=0.97)$, underlying the influence of water on dough rheological behavior previously established [34]. Pasta acceptability was negatively correlated with the RS content $(r=0.97, p<$ $0.05)$ and with fibers $(r=0.96, p<0.05)$, these results supporting Gaita et al. [1] findings which showed that the sensory scores were directly influenced by grape peels level and fibers presence.

\section{Conclusion}

Heat moisture treatment and grape peels can be useful techniques for pasta nutritional and functional value increase. HMT determined higher resistant starch values, while the addition of grape peels resulted in higher pasta fiber and polyphenols contents compared to the control. Dough rheology showed significant changes when HMT was applied and/or when grape peels were added, viscous and elastic modulus showing higher values. Dough resistance to deformation increased when HMT and/or grape peels were used, while the recovery capacity was improved. The sensory profile revealed that pasta from treated wheat flour was associated with elastic, sticky, gummy texture, while the samples containing grape peels were described as nutritious, fruity, sourish, satiating, innovative and fragile. These results evidenced the opportunity to use HMT and/or grape peels in pasta production.

\section{Acknowledgment}

This work was supported by Romania National Council for Higher Education Funding, CNFIS, project number CNFISFDI-2021-0357.

\section{References}

[1]. GAITA, C., ALEXA, E., MOIGRADEAN, D., FILOMENA, C., POIANA, M.-A. (2020),

Mădălina IUGA, Silvia MIRONEASA, Characterization of pasta from heat moisture treated wheat flour and grape peels, Food and Environment Safety, Volume XX, Issue 2-2021, pag. 91 - 100 
Designing of high value-added pasta formulas by incorporation of grape pomace skins, Romanian Biotechnological Letters, 25(3): 1607-1614, (2020)

https://doi.org/10.25083/rbl/25.3/1607.1614

[2]. BENDER, A. B. B., SPERONI, C. S., SALVADOR, P. R., LOUREIRO, B. B., LOVATTO, N. M., GOULART, F. R., LOVATTO, M. T., MIRANDA, M. Z., SILVA, L. P., PENNA, N. G., Grape Pomace Skins and the Effects of Its Inclusion in the Technological Properties of Muffins, Journal of Culinary Science and Technology, 15(2): 143-157, (2017).

https://doi.org/10.1080/15428052.2016.1225535

[3]. ZHU, F., DU, B., ZHENG, L., LI, J., Advance on the bioactivity and potential applications of dietary fibre from grape pomace, Food Chemistry, 186: 207-212, (2015). https://doi.org/10.1016/j.foodchem.2014.07.057

[4]. TANG, G. Y., ZHAO, C. N., LIU, Q., FENG, X. L., XU, X. Y., CAO, S. Y., MENG, X., LI, S., GAN, R. Y., LI, H. BIN., Potential of grape wastes as a natural source of bioactive compounds, Molecules, 23(10): 1-20, (2018). https://doi.org/10.3390/molecules23102598

[5]. KENDALL, C. W. C., ESFAHANI, A., JENKINS, D. J. A., The link between dietary fibre and human health, Food Hydrocolloids, 24: 42-48, (2010). https://doi.org/10.1016/j.foodhyd.2009.08.002

[6]. RASINES-PEREA, Z., KY, I., CROS, G., CROZIER, A., TEISSEDRE, P.L., Grape Pomace: Antioxidant Activity, Potential Effect Against Hypertension and Metabolites Characterization after Intake. Diseases, 6(60): (2018). https://doi.org/10.3390/diseases6030060

[7]. SANT'ANNA, V., CHRISTIANO, F. D. P., MARCZAK, L. D. F., TESSARO, I. C., THYS, R. C. S., The effect of the incorporation of grape marc powder in fettuccini pasta properties, LWT - Food Science and Technology 58(2): 497-501, (2014). https://doi.org/10.1016/j.lwt.2014.04.008

[8]. MIRONEASA, S., IUGA, M., ZAHARIA, D., MIRONEASA, C., Rheological Analysis of Wheat Flour Dough as Influenced by Grape Peels of Different Particle Sizes and Addition Levels, Food and Bioprocess Technology, 12(2): 228-245, (2019). https://doi.org/10.1007/s11947-018-2202-6

[9]. GUZAR, I., Effect of starch-polyphenol interactions on starch hydrolysis. Ontario, Canada: University of Guelpf, (2012).

[10]. COLLAR, C., ARMERO, E., Impact of heat moisture treatment and hydration level on physico-chemical and viscoelastic properties of doughs from wheat-barley composite flours,
European Food Research and Technology, 244(2): 355-366, (2017). https://doi.org/10.1007/s00217-017-2961-8

[11]. LAWAL, O. S., Studies on the hydrothermal modifications of new cocoyam (Xanthosoma sagittifolium) starch, International Journal of Biological Macromolecules, 37(5): 268-277, (2005).

https://doi.org/10.1016/j.ijbiomac.2005.12.016

[12]. CHEN, X., HE, X., FU, X., HUANG, Q., In vitro digestion and physicochemical properties of wheat starch/flour modified by heat-moisture treatment, Journal of Cereal Science, 63: 109115 ,

(2015). https://doi.org/10.1016/j.jcs.2015.03.003

[13]. CETINER, B., ACAR, O., KAHRAMAN, K., SANAL, T., KOKSEL, H., An investigation on the effect of heat-moisture treatment on baking quality of wheat by using response surface methodology, Journal of Cereal Science, 74: 103-111, (2017). https://doi.org/10.1016/j.jcs.2017.01.002

[14]. LAN, H., HOOVER, R., JAYAKODY, L., LIU, Q., DONNER, E., BAGA, M., ... CHIBBAR, R. N., Impact of annealing on the molecular structure and physicochemical properties of normal, waxy and high amylose bread wheat starches, Food Chemistry, 111(3): 663-675,

(2008). https://doi.org/10.1016/j.foodchem.2008.04.055

[15]. ALCAZAR-ALAY, S.C., ALMEIDA MEIRELES, M.A., Physicochemical properties, modifications and applications of starches from different botanical sources, Journal of Food Science and Technology, 35(2): 215-236, (2015). https://doi.org/10.1590/1678-457X.6749

[16]. LI, M., LIU, C., ZHENG, X., LI, L., BIAN, K., Physicochemical properties of wheat flour modified by heat-moisture treatment and their effects on noodles making quality, Journal of Food Processing and Preservation, 44(9): 1-9, (2020). https://doi.org/10.1111/jfpp.14590

[17]. CHANDLA, N. K., SAXENA, D. C., SINGH, S., Processing and evaluation of heat moisture treated (HMT) amaranth starch noodles; An inclusive comparison with corn starch noodles, Journal of Cereal Science, 75: 306-313,

(2017). https://doi.org/10.1016/j.jcs.2017.05.003

[18]. LAZARIDOU, A., MARINOPOULOU, A., BILIADERIS, C. G., Impact of flour particle size and hydrothermal treatment on dough rheology and quality of barley rusks, Food Hydrocolloids, 87: 561-569, (2019). https://doi.org/10.1016/j.foodhyd.2018.08.045

[19]. COLLAR, C., ARMERO, E., Impact of heat moisture treatment and hydration level on physico-chemical and viscoelastic properties of

Mădălina IUGA, Silvia MIRONEASA, Characterization of pasta from heat moisture treated wheat flour and grape peels, Food and Environment Safety, Volume XX, Issue 2-2021, pag. 91 - 100 
doughs from wheat-barley composite flours, European Food Research and Technology, 244(2): 355-366, (2018). https://doi.org/10.1007/s00217-017-2961-8

[20]. BERGMAN, C., GUALBERTO, D., WEBER, C., Development of a hightemperature-dried soft wheat pasta supplemented with cowpea (Vigna unguiculata (L) Walp) - Cooking quality, color, and sensory evaluation, Cereal Chemistry, 71(6): 523-527, (1994).

[21]. IUGA, M., MIRONEASA, S., Application of heat moisture treatment in pasta production, Food Control, 128: 108176, (2021). https://doi.org/10.1016/j.foodcont.2021.108176

[22]. IUGA, M., MIRONEASA, S., Use of grape peels by-product for wheat pasta manufacturing, Plants, 10(5): 926-943, (2021). https://doi.org/10.3390/plants10050926

[23]. IUGA, M., MIRONEASA, S., Simultaneous optimization of wheat heat moisture treatment and grape peels addition for pasta making, LWT - Food Science and Technology, 150: 112011, (2021).

https://doi.org/10.1016/j.lwt.2021.112011

[24]. PEREIRA, P. M., OLIVEIRA, J. C., Measurement of glass transition in native wheat flour by dynamic mechanical thermal analysis (DMTA), International Journal of Food Science and Technology, 35(2): 183-192, (2000). https://doi.org/10.1046/j.13652621.2000.00289.x

[25]. MOREIRA, R., CHENLO, F., TORRES, M. D., PRIETO, D. M., Influence of the particle size on the rheological behaviour of chestnut flour doughs, Journal of Food Engineering, 100(2): 270-277, (2010). https://doi.org/10.1016/j.jfoodeng.2010.04.009

[26]. MELILLI, M. G., PAGLIARO, A., SCANDURRA, S., GENTILE, C., DI STEFANO, V., Omega-3 rich foods: Durum wheat spaghetti fortified with Portulaca oleracea, Food Bioscience, 37: 100730, (2020). https://doi.org/10.1016/j.fbio.2020.100730

[27]. BUSTOS, M. C., PAESANI, C., QUIROGA, F., LEÓN, A. E. Technological and sensorial quality of berry-enriched pasta, Cereal Chemistry, 96(5): 967-976, (2019). https://doi.org/10.1002/cche.10201

[28]. ACUN, S., GÜL, H., Effects of grape pomace and grape seed flours on cookie quality, Quality Assurance and Safety of Crops and Foods, 6(1): 81-88, (2014). https://doi.org/10.3920/QAS2013.0264

[29]. IUGA, M., MIRONEASA, S., A review of the hydrothermal treatments impact on starch based systems properties, Critical Reviews in Food Science and Nutrition, 60(22): 3890-
3915 ,

(2020).

https://doi.org/10.1080/10408398.2019.1664978

[30]. SUN, L., MIAO, M., Dietary polyphenols modulate starch digestion and glycaemic level: a review, Critical Reviews in Food Science and Nutrition, 8398: 1-15, (2019). https://doi.org/10.1080/10408398.2018.1544883

[31]. GOMES, T. M., TOALDO, I. M., HAAS, I. C. DA S., BURIN, V. M., CALIARI, V., LUNA, A. S., DE GOIS, J. S., BORDIGNONLUIZ, M. T., Differential contribution of grape peel, pulp, and seed to bioaccessibility of micronutrients and major polyphenolic compounds of red and white grapes through simulated human digestion, Journal of Functional Foods, 52: 699-708, (2019). https://doi.org/10.1016/j.jff.2018.11.051

[32]. MADEKA, H., KOKINI, J. L., Changes in rheological properties of gliadin as a function of temperature and moisture: Development of a state diagram, Journal of Food Engineering, 22(1-4): 241-252, (1994). https://doi.org/10.1016/0260-8774(94)90033-7

[33]. COLLAR, C., E. ARMERO., Value-Added of heat moisture treated mixed flours in wheat based matrices: a functional and nutri- tional approach, Food and Bioprocess Technology, 11 (8): $\quad$ 1536-51, (2018). https://doi:10.1007/s11947-018-2125-2

[34]. RONDA, F., PÉREZ-QUIRCE, S., ANGIOLONI, A., COLLAR, C., Impact of viscous dietary fibres on the viscoelastic behaviour of gluten-free formulated rice doughs: A fundamental and empirical rheological approach, Food Hydrocolloids, 32(2): 252-262, (2013). https://doi.org/10.1016/j.foodhyd.2013.01.014

[35]. WEEGELS, P.L., ORSEL, R., VAN DE PIJPEKAMP, A.M., LICHTENDONK, W.J., HAMER, R.J., SCHOFIELD, J.D., Fundamental properties of low $\mathrm{Mr}$ wheat proteins. II. Effects on dough properties. Journal of Cereal Science, 21: 117-126, (1995).

[36]. BARROS, J. H. T., TELIS, V. R. N., TABOGA, S., FRANCO, C. M. L., Resistant starch: effect on rheology, quality, and staling rate of white wheat bread, Journal of Food Science and Technology, 55(11): 4578-4588, (2018). $\quad$ https://doi.org/10.1007/s13197-0183393-6

Mădălina IUGA, Silvia MIRONEASA, Characterization of pasta from heat moisture treated wheat flour and grape peels, Food and Environment Safety, Volume XX, Issue 2 - 2021, pag. 91 - 100 